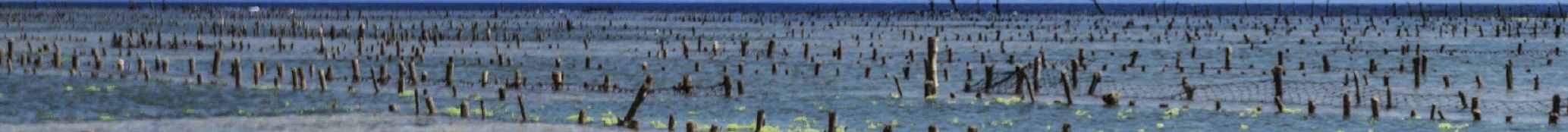

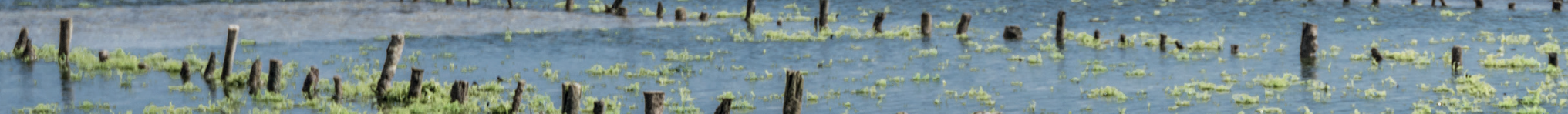

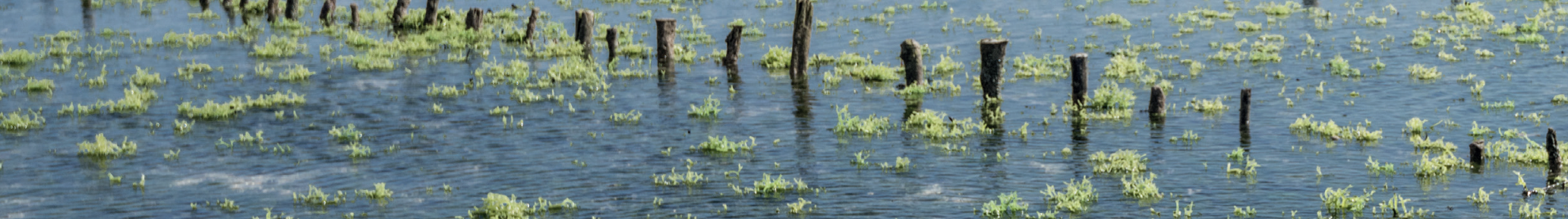

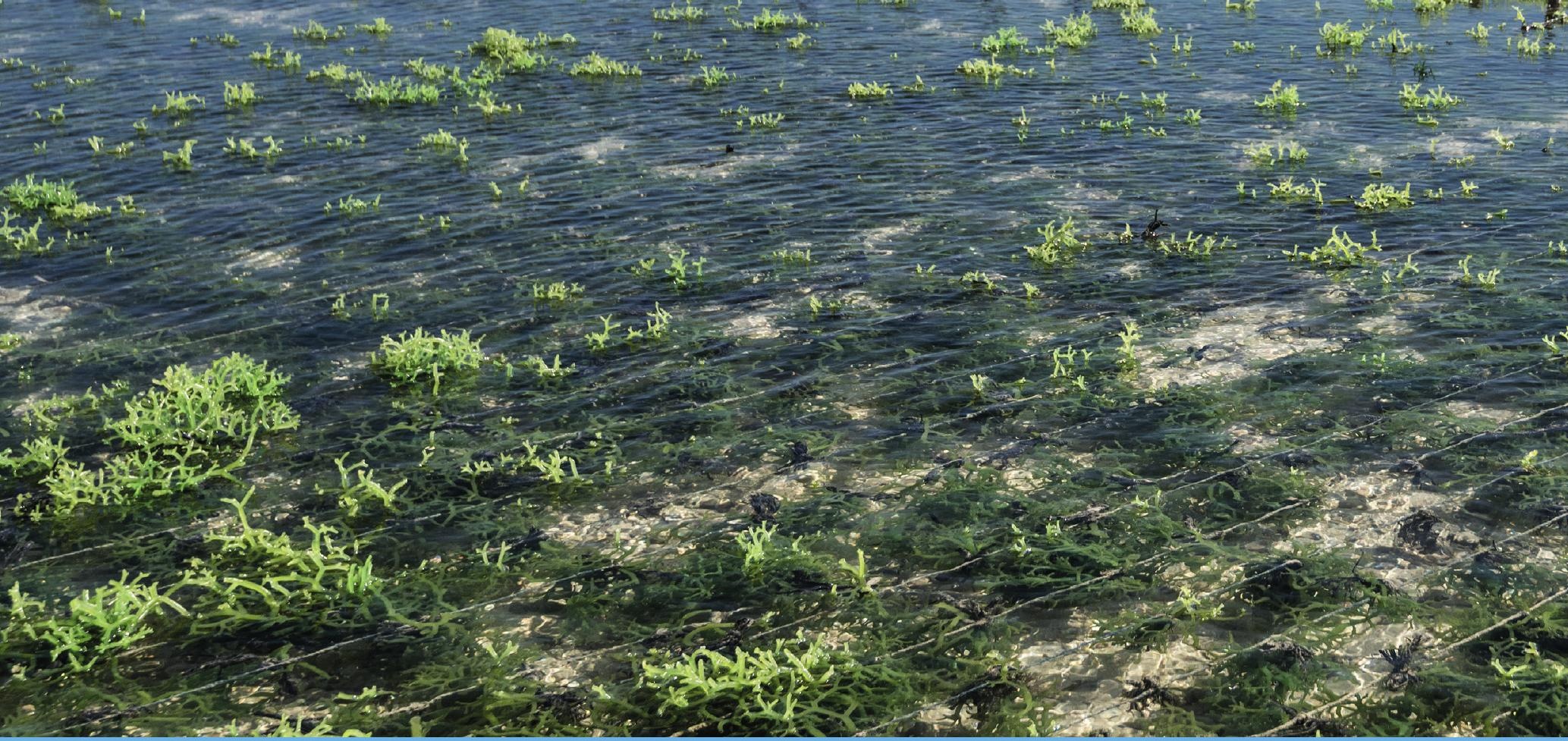

\title{
Investigating the need for environmental risk assessment of chemical crop protection practices in seaweed
}

Bas Buddendorf, Mechteld ter Horst, Ivo Roessink 



\section{Investigating the need for environmental risk assessment of chemical crop protection practices in seaweed}

Bas Buddendorf, Mechteld ter Horst, Ivo Roessink

This research was subsidised by the Dutch Ministry of Agriculture, Nature, and Food Quality (Ministerie van Landbouw, Natuur en Voedselkwaliteit) (project number 4318300137-WENR 2021/ KB-35-004-001 Aquatic Systems).

Wageningen Environmental Research

Wageningen, September 2021

Reviewed by:

R.W. Nauta, Project manager - Researcher (Wageningen Marine Research)

Approved for publication:

Bram de Vos, team leader of Team Environmental Risk Assessment

Report 3113

ISSN 1566-7197 
Buddendorf, W.B., M. ter Horst, I. Roessink, 2021. Investigating the need for environmental risk assessment of chemical crop protection practices in seaweed. Wageningen, Wageningen

Environmental Research, Report 3113. 26 pp.; 4 fig.; 2 tab.; 59 ref.

Seaweed has the potential to deliver more food to an increasing world population. Diseases endanger production security and yield of any farm, seaweed farming is no exception, hence crop protection plans may be developed that include the use of chemical crop protection either directly or indirectly in co-cropping systems. This document reports a first attempt to map the extent to which chemicals are being used in seaweed production, which production systems are used, where potential risks of the use of chemicals resulting from protection of seaweed production (or co-produced products) against diseases can be anticipated, and how this could be taken into account for future work. The investigations concerning open sea production systems indicate that for the control of pests and diseases in the described cultivation systems only prevention, monitoring and mechanical/physical measures are common, at least for Indonesia. In contrast, results from closed pond- or tank-based multi-trophic systems where seaweed can be included for example as feed or filter, or for biomass production, indicate some reasons for concern. Uptake and sorption of veterinary medicinal products and other chemicals can lead to additional input to shrimp and/or fish (via feed) or to the environment (via disposal of filter material). The ERA-AQUA model, originally developed for risk assessment of aquaculture production of fish and shrimp, was identified as possible means to further explore the fate of chemicals used in land-based multi-trophic production systems, for their bioaccumulation and biomagnification potential and possible risk for the environment, the produced goods (fish/shrimp), and finally human health.

Keywords: environmental risk assessment, seaweed, chemical crop protection, multi-trophic system, shrimp, pond aquaculture, ERA-AQUA

The pdf file is free of charge and can be downloaded at https://doi.org/10.18174/550814 or via the website www.wur.nl/environmental-research (scroll down to Publications - Wageningen Environmental Research reports). Wageningen Environmental Research does not deliver printed versions of the Wageningen Environmental Research reports.

2021 Wageningen Environmental Research (an institute under the auspices of the Stichting Wageningen Research), P.O. Box 47,6700 AA Wageningen, The Netherlands, T +31 (0)317 4807 00, www.wur.nl/environmental-research. Wageningen Environmental Research is part of Wageningen University \& Research.

- Acquisition, duplication and transmission of this publication is permitted with clear acknowledgement of the source.

- Acquisition, duplication and transmission is not permitted for commercial purposes and/or monetary gain.

- Acquisition, duplication and transmission is not permitted of any parts of this publication for which the copyrights clearly rest with other parties and/or are reserved.

Wageningen Environmental Research assumes no liability for any losses resulting from the use of the research results or recommendations in this report.

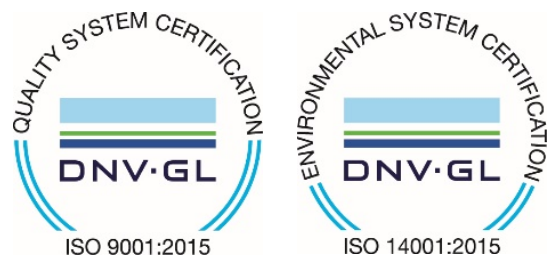

In 2003 Wageningen Environmental Research implemented the ISO 9001 certified quality management system.

Since 2006 Wageningen Environmental Research has been working with the ISO 14001 certified environmental care system.

By implementing the ISO 26000 guideline, Wageningen Environmental Research can manage and deliver its social responsibility.

Wageningen Environmental Research report 3113 | ISSN 1566-7197

Photo cover: Shutterstock 


\section{Contents}

$\begin{array}{ll}\text { Verification } & 5\end{array}$

$\begin{array}{ll}\text { Preface } & 7\end{array}$

$\begin{array}{ll}\text { Summary } & 9\end{array}$

$\begin{array}{llr}1 & \text { Introduction } & 11\end{array}$

2 Environmental risks of chemical crop protection practices in seaweed $\begin{array}{ll}\text { cultivation in open sea } & 13\end{array}$

2.1 Seaweed farming in open sea in Indonesia 13

2.2 Pests/ diseases and corresponding control measures $\quad 14$

3 Seaweed cultivation in multi-trophic pond/tank based systems 17

3.1 Seaweed as part of pond/tank based integrated multi-trophic systems $\quad 18$

$\begin{array}{ll}3.2 & \text { Integration with ERA-AQUA } \\ \end{array}$

$\begin{array}{ll}\text { References } & 23\end{array}$ 



\section{Verification}

Report: 3113

Project number: 4318300137

Wageningen Environmental Research (WENR) values the quality of our end products greatly. A review of the reports on scientific quality by a reviewer is a standard part of our quality policy.

Approved reviewer who stated the appraisal,

position: Project manager - Researcher

name: $\quad$ R.W. Nauta

date: $\quad$ August $30^{\text {th }}, 2021$

Approved team leader responsible for the contents,

name: Bram de Vos

date: $\quad$ August $30^{\text {th }}, 2021$ 


\section{Preface}

Ending food shortages is an important aim of the Sustainable Development Goal 2 of the United Nations. It aims to make sufficient and nutritious food available to everyone by 2030 . In pursuit of this goal, to date, the world's marine environments are utilised only to a limited extent. The overarching aim of this 'Knowledge Base' (KennisBasis) project is the development of interdisciplinary skills and knowledge to benefit the sustainable production of high-value produce and raw materials from the marine environment, thus contributing to food security globally. Here, aquaculture systems with primary producers like seaweed and micro-algae, potentially as part of multi-trophic systems that include, for example, fish or shrimp will have a prominent role in this project.

This report has been produced with input from colleagues at WENR: Mechteld ter Horst for section 2; Bas Buddendorf for sections 1,3, and 4; Ivo Roessink for contributions to sections 1 and 4 and discussions. Special thanks to Andreas Focks (Osnabrück University, formerly WENR) for vital discussions and inputs at the early stages of this work.

This report focusses strictly on environmental risk related aspects of seaweed aquaculture. Further details about the Aquatic systems project (running from 2019 - 2022) can be found on the project webpage: https://research.wur.nl/en/projects/aquatic-systems-kb-35-004-001, and in Debrot (2020). 


\section{Summary}

This document reports a first attempt to approach the question in how far chemicals are being used for seaweed production, which production systems are used, where potential risks of the use of chemicals resulting from protection of seaweed production (or co-produced products) against pests and diseases can be anticipated, and how this could be taken into account for future work. Two main cropping systems are investigated. Firstly, open sea seaweed farming is discussed, using seaweed farming in Indonesia, a major seaweed producing country, as an example. Secondly, on-land tank/pond systems are addressed. Pond systems are used for the production of, for example, fish and shrimp, either in mono-culture or in multi-trophic co-cropping systems.

With respect to open sea seaweed cultivation we conclude that for the control of pests and diseases in the described cultivation systems only prevention, monitoring and mechanical/physical measures are common in Indonesia. Risks for the marine environment are not expected from treatments with chemical pest control products or biological pest control agents as there are no signs these kinds of products are authorised and used in seaweed cultivation in open sea. This does not mean that there is no potential for environmental risk to the marine environment but this risk is predominantly a result of large scale commercial seaweed farming (e.g., introduction of alien species, marine pollution).

There are expected benefits of using seaweed as part of multi-trophic pond/tank production systems, like increased water quality, diversification of produced goods, and reduced need for feed. However, there remain potential risks to human health and the environment from the use of chemicals (like veterinary medicinal products (VMPs) and/or pesticides) in pond aquaculture. The current available data to assess the hazard of for example pesticides in seaweed is very limited, and monitoring data is not readily available. It remains unclear how integrated multi-trophic systems compare with traditional monoculture pond systems, and adding seaweed to pond systems to act as biofilters may involve a risk of bioaccumulation of pesticides and/or VMPs. An existing model (ERA-AQUA, https://www.eraaqua.wur.nl/) can be used to assess the risk for four endpoints: 1) the targeted produce; 2) aquatic ecosystems receiving aquaculture effluents; 3) consumers; and 4) the trade of harvested aquatic animals. It appears conceptually possible to include a seaweed compartment into the ERA-AQUA model. With such an addition, it can be used in the risk assessment of integrated multi-trophic aquaculture systems. Given the expected increase in the number of these systems, it would seem a good opportunity for development and further research. 
Seaweed has been harvested globally as direct food source, as staple ingredient in our food and to produce derivative chemicals that can be used for various industrial, pharmaceutical or food products, with carrageenan and agar as the major derivative products. Seaweed production is seen as one particularly interesting method for biomass production, having its anticipated role especially for green energy and for protein from sea programs. As such, seaweed has the potential to deliver more food to an increasing world population. The most widely cultivated seaweed species include Eucheuma spp., Saccharina japonica (Japanese kelp), Gracilaria spp., Undaria pinnatifida (wakame) and Kappaphycus alvarezii (elkhorn sea moss) (Table 1). Tropical seaweed species, like e.g., K. alvarezii and Eucheuma spp. are used as raw material for carrageenan extraction. Some species (e.g. U. pinnatifida, Porphyra spp. and Caulerpa spp., produced in East and Southeast Asia) are produced almost exclusively for direct human consumption, although low-grade products and scraps from processing factories are used for other purposes, including feed for abalone culture (FAO, 2018). The red algae Gracilaria contributes approximately $66 \%$ of the total agar production (Pereira and Yarish, 2008), but is also used for human consumption. S. japonica is a temperate cold water species mostly cultivated in the western Pacific (China, Japan, the Republic of Korea and the Democratic People's Republic of Korea) with China being the largest producer by far. S. japonica is popular as "kombu" in Japanese cuisine. Pyropia and Porphyra species is used to make Nori to wrap sushi. Other species like Spirulina spp. (cyanobacteria) and the micro-algae Chlorella spp. (a freshwater species),

Haematococcus pluvialis, and Nannochloropsis spp. are cultivated in many countries for the production of human nutrition supplements and other uses (FAO, 2018).

After China, Indonesia is the second biggest seaweed producer in the world, contributing to $38 \%$ of the global seaweed market. Indonesia is currently the world's largest producer of agar- and carrageenan-bearing seaweeds, accounting for 61 percent of world production in 2010. Kappaphycus and Eucheuma are the main cultivated species in Indonesia (Valderrama et al., 2013). Almost all of the Indonesian islands are currently planted with different strains or varieties of either Kappaphycus and Eucheuma using fixed-off bottom, hanging long-line and various raft methods, involving tens of thousands of coastal families (Neish 2013; Hurtado et al., 2014). Indonesia is also a major center for the production of Gracilaria (agarophytes) (Hurtado et al., 2014).

Table 1 World aquaculture production of aquatic plants (thousand tonnes, live weight).

\begin{tabular}{|c|c|c|c|c|c|c|c|c|}
\hline Species item & 2005 & 2010 & 2011 & 2012 & 2013 & 2014 & 2015 & 2016 \\
\hline $\begin{array}{l}\text { Eucheuma seaweeds nei, Eucheuma } \\
\text { spp. }\end{array}$ & 987 & 3481 & 4616 & 5853 & 8430 & 9034 & 10190 & 10519 \\
\hline Japanese kelp, Laminaria japonica & 4371 & 5147 & 5257 & 5682 & 5942 & 7699 & 8027 & 8219 \\
\hline Gracilaria seaweeds, Gracilaria spp. & 933 & 1691 & 2171 & 2763 & 3460 & 3751 & 3881 & 4150 \\
\hline Wakame, Undaria pinnatifida & 2440 & 1537 & 1755 & 2139 & 2079 & 2359 & 2297 & 2070 \\
\hline $\begin{array}{l}\text { Elkhorn sea moss, Kappaphycus } \\
\text { alvarezii }\end{array}$ & 1285 & 1888 & 1957 & 1963 & 1726 & 1711 & 1754 & 1527 \\
\hline Nori nei, Porphyra spp. & 703 & 1072 & 1027 & 1123 & 1139 & 1142 & 1159 & 1353 \\
\hline Seaweeds nei, Algae & 1844 & 3126 & 2889 & 2815 & 2864 & 449 & 775 & 1049 \\
\hline Laver (nori), Porphyra tenera & 584 & 564 & 609 & 691 & 722 & 674 & 686 & 710 \\
\hline $\begin{array}{l}\text { Spiny eucheuma, Eucheuma } \\
\text { denticulatum }\end{array}$ & 172 & 259 & 266 & 288 & 233 & 241 & 274 & 214 \\
\hline $\begin{array}{l}\text { Fusiform sargassum, Sargassum } \\
\text { fusiforme }\end{array}$ & 86 & 78 & 111 & 112 & 152 & 175 & 189 & 190 \\
\hline Spirulina nei, Spirulina spp. & 48 & 97 & 73 & 80 & 82 & 86 & 89 & 89 \\
\hline Brown seaweeds, Phaeophyceae & 30 & 23 & 28 & 17 & 16 & 19 & 30 & 34 \\
\hline Others & 20 & 28 & 27 & 28 & 18 & 15 & 14 & 17 \\
\hline Total & 13503 & 18992 & 20785 & 23555 & 26863 & 27356 & 29365 & $30 \quad 139$ \\
\hline
\end{tabular}

Source: FAO (2018). Note that Laminaria japonica, used by the FAO, is an unaccepted synonym for Saccharina japonica. 
Like with any other form of mass-cultivation, also seaweed production systems are susceptible to diseases and pests. Both endanger production security and yield of any farm, seaweed farming is no exception, hence seaweed producers might develop crop protection plans that may include the use of chemical crop protection either directly or indirectly in co-cropping systems.

Two main cropping systems are investigated. Firstly, open sea seaweed farming is discussed, using seaweed farming in Indonesia, a major seaweed producing country, as an example. Here challenges in pest control are related to the scale of operation of a seaweed farm and to working in an open system where pest species may enter the cropped area unhindered. Secondly, on-land pond systems are addressed. Pond systems are used for the production of, for example, fish and shrimp, either in monoculture or in multi-trophic co-cropping systems. Here, challenges are related to direct or indirect exposure of seaweed via pest control that may be intended for other species in the system (e.g., against white spot syndrome in shrimp). 


\section{Environmental risks of chemical crop protection practices in seaweed cultivation in open sea}

\subsection{Seaweed farming in open sea in Indonesia}

Eucheuma and Kappaphycus, the most cultivated species in Indonesia, are generally grown within coastal areas, submerged in water near the surface for photosynthesis (although these seaweeds can be placed in deeper waters, as long as water is clear), thriving in fast moving waters, but without too much wave action (Waters et al, 2019).

Eucheuma and Kappaphycus seaweeds are generally farmed in two ways in Indonesia: 1) the offbottom line method, which generally occurs in shallow waters or 2) the floating long-line method, which is suitable for areas where the currents are weak or the ocean is too deep for the off-bottom line method (Figure 1).

With the floating long-line method the lines are anchored in the seabed and seaweed is hung from ropes that are suspended by floaters. The off-bottom line method is constructed as follows: i) wooden stakes are driven into the seabed at a 5 to 10 meter spacing, ii) monofilament nylon or polypropylene ropes are attached and suspended between the stakes. The line sits 20 to 30 centimetres above the seafloor, the water needs to be deep enough to ensure that the seaweeds are not exposed during low tide.

In both methods, small fragments of seaweed, either cuttings from existing lines, a seed nursery, and/or purchased seed, are tied to the lines. Under proper growth and maintenance conditions, the seaweeds reach 10 times their original size after 6 to 8 weeks, through either method of farming (McHugh, 2003).
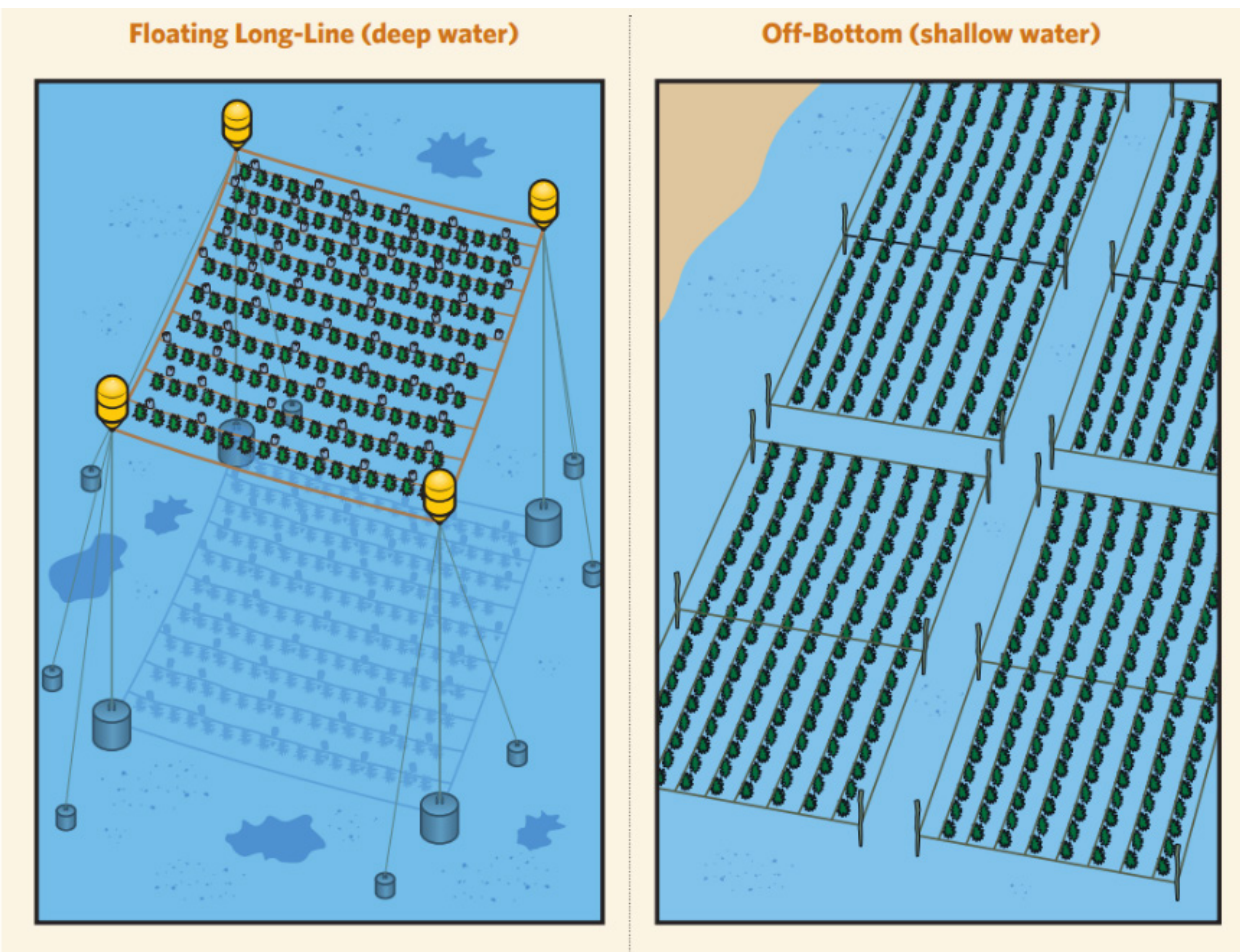

Figure 1 Floating long-line method (left hand side) and the off-bottom line method (right hand side). Source: Waters et al., (2019). 


\subsection{Pests/ diseases and corresponding control measures}

Occurrence of pests and diseases are observed internationally in seaweed aquaculture (Watkiss et al., 2012; Hurtado et al., 2017; Quiaoit et al., 2018). Ward et al., (2019) provide a review of diseases that have been reported in the scientific literature for species of red (e.g. Eucheuma, Gracilaria, Kappaphycus) and brown seaweeds (e.g. Japanese kelp), focusing on the major seaweed crops grown in Asia. Table 2 shows the most common diseases and disease agents of Kappaphycus in Asia. Most relevant disease affecting Kappaphycus and Eucheuma spp. is ice-ice disease. It is characterized by a whitening of the thallus in response to environmental stress and the action of opportunistic pathogenic bacteria (Ward et al.,2019). Table 2 shows that several bacterial species and complexes have been linked to ice-ice disease, but also marine fungi (Aspergillus spp. and Phoma spp.) may induce ice-ice symptoms (demonstrated in both Kappaphycus alvarezii and $K$. striatum under laboratory conditions by Solis et al., 2010).

Another major problem affecting the yields and quality of commercial cultivated seaweed is epiphytism. Marine epiphytes may, for example, be other unwanted algal species, bacteria, and fungi. Almost all marine epiphytes attract many grazers that feed on them and on the host leading to additional yield reduction (Ingle et al., 2018). Different environmental conditions like the temperature, salinity, and current of seawater and intensity of light and nutrient availability may be important contributors to epiphytism.

One of the main problems of commercially cultivated Kappaphycus and Eucheuma spp. in Southeast Asia are epiphytic filamentous algae which are responsible for a significant decrease in both the production of biomass and carrageenan quality (Ward et al.,2019). Heavy infections with epiphytic algae have also shown to weaken Kappaphycus and Eucheuma, making it susceptible to bacterial attack (Vairappan et al., 2008).

Table 2 Diseases and disease agents of Kappaphycus in Asia. Source: Table 2 in Ward et al., 2019.

\begin{tabular}{|c|c|c|c|c|c|}
\hline Host & Disease & Disease agents & Taxonomy & Distribution & References \\
\hline $\begin{array}{l}\text { Kappaphycus } \\
\text { alvarezii }\end{array}$ & $\begin{array}{l}\text { Epiphytic } \\
\text { filamentous } \\
\text { algae }\end{array}$ & $\begin{array}{l}\text { Melanothamnus (as } \\
\text { Neosiphonia) apiculata }\end{array}$ & $\begin{array}{l}\text { Rhodophyta } \\
\text { (Eukaryota) }\end{array}$ & $\begin{array}{c}\text { Philippines } \\
\text { Indonesia } \\
\text { Malaysia }\end{array}$ & $\begin{array}{l}\text { Vairappan et al. } \\
\text { (2008) }\end{array}$ \\
\hline \multirow[t]{7}{*}{$\begin{array}{l}\text { K. alvarezii } \\
\text { and } K . \\
\text { striatus }\end{array}$} & \multirow[t]{6}{*}{ Ice-ice disease } & $\begin{array}{l}\text { Cytophaga- } \\
\text { Flavobacterium } \\
\text { complex, Vibrio sp. }\end{array}$ & $\begin{array}{l}\text { Gram-negative } \\
\text { bacteria }\end{array}$ & Philippines & $\begin{array}{r}\text { Largo, Fukami, and } \\
\text { Nishijima (1995) }\end{array}$ \\
\hline & & $\begin{array}{l}\text { Alteromonas, } \\
\text { Pseudoalteromonas, } \\
\text { Aurantomonas }\end{array}$ & $\begin{array}{l}\text { Gram-negative } \\
\text { bacteria }\end{array}$ & Indonesia & $\begin{array}{l}\text { Syafitri, Prayitno, } \\
\text { Ma'ruf, and } \\
\text { Radjasa (2017) }\end{array}$ \\
\hline & & $\begin{array}{l}\text { Aspergillus ochraceus, } \\
\text { A. terreus, Phoma sp. }\end{array}$ & $\begin{array}{l}\text { Ascomycota } \\
\text { (Eukaryota) }\end{array}$ & Philippines & $\begin{array}{l}\text { Solis, Draeger, and } \\
\text { de la Cruz(2010) }\end{array}$ \\
\hline & & Undetermined & Undetermined & India & $\begin{array}{l}\text { Arasamuthu and } \\
\text { Patterson } \\
\text { Edwards (2018) }\end{array}$ \\
\hline & & Undetermined & Undetermined & China & $\begin{array}{l}\text { Pang, Liu, Liu and Li } \\
\text { (2015) }\end{array}$ \\
\hline & & $\begin{array}{l}\text { Neosiphonia sp., } \\
\text { Polysiphonia sp., } \\
\text { Gracilaria sp., Hypnea } \\
\text { sp., Acanthophora sp. }\end{array}$ & $\begin{array}{l}\text { Rhodophyta } \\
\text { (Eukaryota) }\end{array}$ & China & Pang et al. (2015) \\
\hline & $\begin{array}{l}\text { Epiphytic } \\
\text { filamentous } \\
\text { algae }\end{array}$ & Cladophora sp. & $\begin{array}{l}\text { Chlorophyta } \\
\text { (Eukaryota) }\end{array}$ & China & Pang et al. (2015) \\
\hline
\end{tabular}

Several control and mitigation measures have been used to put an end to, or mitigate the impact and spread of disease and pest outbreaks on commercially cultivated seaweed. Lately, analogous to 
Integrated Pest Management (IPM) in terrestrial agriculture, Marine Integrated Pest Management has been advocated (MIPM; Ingle et al., 2018). Basically, pest management is done along the lines and in the order of prevention, monitoring in order to make decisions on control and direct measures. Direct measures can be mechanistically/physically or biologically, with chemical control as a last resort.

Prevention measures like optimal sites in terms of physical, geographic, and pollution parameters for seaweed farming, selection of suitable seaweed species and using healthy seedlings are common practice. The current technique for decreasing the impact of pest epiphytes is to monitor cultivated populations and remove the pests by hand as quickly as possible before they can reproduce and spread (Ward et al.,2019). The following quote on current practices for the control of ice-ice disease is taken from Ward et al., (2019): "The development of ice-ice symptoms in

Kappaphycus and Eucheuma is thought to be the result of stress to the host from abiotic conditions, such as temperature and salinity (Vairappan et al., 2008) and light intensity and water movement (Hurtado \& Critchley, 2006) in combination with the action of opportunistic bacteria (Largo et al., 1995; Uyenco et al., 1981). The triggers behind disease onset and progression are not well understood, and as a result, no effective management protocols that are cost effective have been developed to date."

No findings on the use of biological pest control agents or chemical pest control in seaweed cultivation in open sea, other than the use of organic acids or acid ionic(electrolysed) water were found in literature. This is in line with Ingle et al., (2018) who state that there is a lack of commercially available pesticides that can be used in the seaweed cultivation, particularly in the near shore or offshore environments. In the Republic of Korea there are no authorizations for the use of chemical pesticides in seaweed cultivation (personal communication Jina Oh, NAS-RDA). Use of such products in seaweed cultivation is therefore forbidden. Illegal uses can however not be excluded. In the Republic of Korea, there was a case in which the use of pesticides for laver (Porphyra spp.) farming was discovered (personal communication Jina Oh NAS-RDA).

Ingle et al., (2018) also state that, at low levels, some chemicals such as copper can be applied for the onshore cultivation or nursery level for control of certain epiphytes.

As mentioned before disinfection with acids baths occurs commonly. The washing of Pyropia blades in acid solutions is a widespread practice in the Republic of Korea and is often used in an attempt to control all diseases, albeit ineffective for some diseases like Olpidiopsis (Kim et al., 2014). A common method used to disinfect seaweed cultivated in open sea is to pull the seaweed nets onto a boxshaped ship carrying containers that store a disinfectant solution, such as acid solution, and then immersing the seaweed adhering to the net in the disinfectant solution in the container. It is not clear whether this disinfection method is used in cultivation of Kappaphycus and Eucheuma in Indonesia.
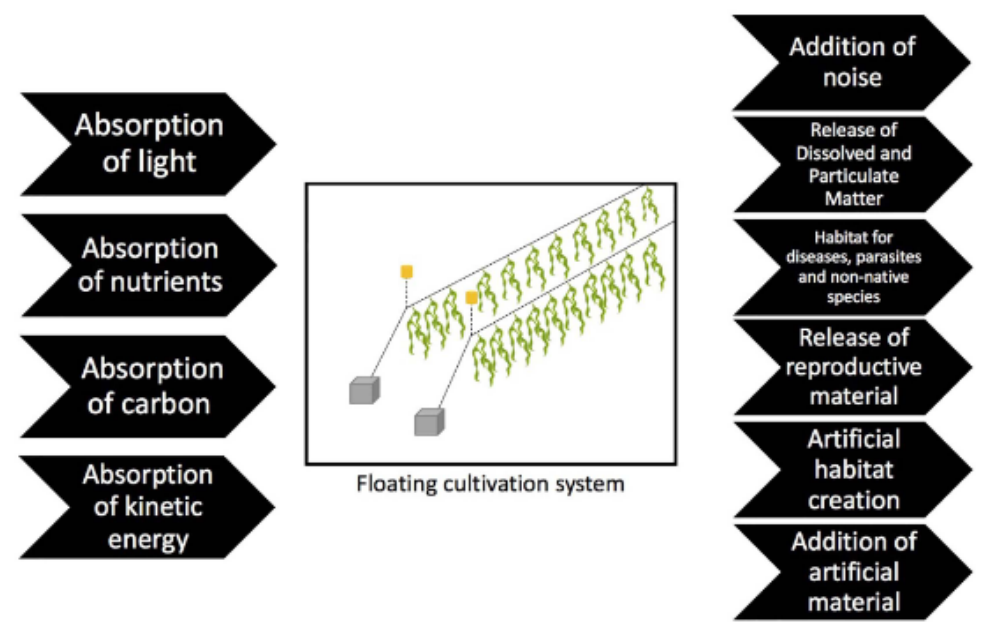

Figure 2 Drivers for environmental change in relation to seaweed farming. Source: Campbell et al., 2019. 
Compared to other types of aquaculture, seaweed farming has a generally low impact on the environment. Nonetheless, there are potential direct or indirect negative effects of especially largescale seaweed farming, such as introduction of alien species and changes in local environmental conditions (Eggertsen and Halling, 2020). Other risks stemming from non-chemical sources are inherently associated with large scale commercial seaweed farming. Campbell et al., (2019) provide a systematic review of the ecosystem changes likely to be associated with large scale commercial seaweed farming. Although focusing on cultivation of kelp in Europe, many lessons are drawn from Asia. Campbell et al., (2019) identified the key drivers for environmental change (Figure 2).

According to Campbell et al., (2019) the three major environmental changes of greatest concern are:

- facilitation of disease,

- alteration of population genetics,

- wider alterations to the local physiochemical environment.

Yet, they also remark that the true extent of some environmental changes are surrounded by high levels of uncertainty.

Pest control strategies in marine fish/shell fish aquaculture might contribute to deterioration of the marine environment. The use of chemical pest control products in marine fish/shellfish aquaculture, especially disinfectants and antibiotics, causes effects in the marine environment. It is not clear whether pest control strategies in large-scale seaweed farming have similar impacts on the environment.

For now we conclude that for the control of pests and diseases in the described cultivation systems only prevention, monitoring and mechanical/physical measures are common in Indonesia. Risks for the marine environment are not expected from treatments with chemical pest control products or biological pest control agents as there are no signs these kind of products are authorised and used in seaweed cultivation in open sea. This does not mean that there is no potential for risk to the marine environment but this risk is predominantly a result of large scale commercial seaweed farming. 


\section{Seaweed cultivation in multi-trophic pond/tank based systems}

In mariculture there are good examples of integrated systems with seaweed and salmon. These are generally open water net pen systems (Petrell and Alie 1996, Chopin et al., 1999) and there are expected beneficial effects of integrating these systems that result in increased seaweed production and improved water quality (Troell et al., 1997, Chopin et al., 1999). The majority of salmon production is sea-based with an annual global export valued of more than 25 billion USD (FAO Globefish 2020). Yet the industry is increasingly facing issues linked to sea-lice infestation, environmental pollution, escaped animals, and a high carbon footprint (Liu et al., 2016).

Consequently, the commercial farming of salmon using land-based pond or tank production systems could increase in the future (Bjørndal and Tusvik 2019). Whereas the majority of research on integrated multi-trophic has been based on seaweed and fish, the shrimp aquaculture industry has grown substantially since the 1990s (Copertino et al., 2009), and continues to grow to this day (FAO 2020a, FAO 2020b). There is an increase in both demand and production losses (FAO 2020b), which means more sustainable solutions have to be incorporated.

In $2018,62.5 \%$ of farmed fish is produced by inland aquaculture (i.e., in pond/tank systems), of which $91.5 \%$ are finfish (FAO 2020a). Although multi-trophic production using filter feeding animals and/or seaweed is a common practice in Asia, Central and Eastern Europe and Latin America, farmed larger carnivorous fish and shrimp are of higher economic value to the grower (FAO 2020a). Their production systems tend to be monocultures (Neori 2009). Typical for monocultures, they have a relatively high demand for artificial feed, antibiotics, disinfectants, and chemical pest control. Moreover, with increased production demands this could lead to unacceptable levels of excess nutrients and chemicals being released into the environment via effluent water and issues with longterm viability and sustainability of the food production chain.

The application of integrated multi-trophic systems in monoculture systems could help to reduce or alleviate some of the issues. There are indications such systems can increase water quality (e.g., Evans and Langdon 2000, Viera et al., 2005, Paul and de Nys 2008, Copertino et al., 2009). In turn, increasing water quality may reduce the risk of disease and thus the need for antibiotics, disinfectants, and chemical pest control. There are indications that product quality can increase while the need for artificial feed is decreased (Cruz-Suárez et al., 2010, Rosales et al., 2019). Additionally, seaweed can be used as an extra crop for the producer allowing for a further diversification of production systems (Neori 2009).

Despite the reported benefits of multi-trophic systems, there are potential risks to human health and the environment from the use of veterinary medicinal products (VMPs) in pond aquaculture (Rico et al., 2013). The current available data to assess the hazard of for example pesticides in seaweed is very limited, and monitoring data is not readily available (Banach et al., 2020). It is unclear how integrated multi-trophic systems compare with traditional monoculture pond systems, and adding seaweed to pond systems to act as biofilters may involve a risk of bioaccumulation of pesticides and/or VMPs. Rico et al., (2013) have developed a model (called ERA-AQUA) that can be used to assess the risk from VMPs used in aquaculture in pond systems. The ERA-AQUA model in its current form considers four endpoints: 1 ) the targeted produce; 2) aquatic ecosystems receiving aquaculture effluents; 3) consumers; and 4) the trade of harvested aquatic animals (Rico et al., 2013).

Pond or tank-based systems can have different set-ups with a varying degree of connection to open surface waters. Pond systems are often directly connected to a canal, stream, river or directly to the sea via their irrigation systems and may even experience flooding with tidal cycles. In such cases they are likely similar to near shore, open sea farming in terms of potential environmental impacts. For tank aquaculture systems there are open, semi open and recirculation aquaculture systems (RAS). Open systems, like ponds, generally have a flow-through of water, semi-open systems make use of tanks that are refilled and flushed (i.e., are "connected" at intervals), and RAS systems are completely 
closed off and should have no open connection to surface water. In the following section, we will first look at the function of seaweed in pond/tank production systems and what sources of potential risks to human health there are, next we will link seaweed to the ERA-AQUA model and discuss the adaptions that would be required to incorporate a seaweed-component to the ERA-AQUA model.

\title{
3.1 Seaweed as part of pond/tank based integrated multi- trophic systems
}

\begin{abstract}
A beneficial use of seaweed is as feed for animals integrated in the multi-trophic system. This can reduce the need of artificial feed greatly. For example, Cruz-Suárez et al., (2010) show the inclusion of Ulva clathrata as a food resource for the shrimp Litopenaeus vannamei can reduce the need for artificial feed while leading to increased growth rates, reduce lipid content and increase carotenoid content. However, not all seaweed species will be equally nutritious of beneficial, for example Viera et al., (2005) showed differing feed intake rates, feed conversion ratios and protein efficiency ratios for three red algae (Hynea spinella, H. musciformis, and Gracilaria cornea), which could have implications for the optimal choice of seaweed species in a multi-trophic set-up.
\end{abstract}

Another widely reported reason to include seaweed in integrated multi-trophic systems is the role they can play as biofilter. Complex multi-tank semi-recirculation systems using seaweed as biofilter of effluent water showed an improved $\mathrm{pH}$ balance, a reduced water use, a reduced nutrient load in the environment and improved water quality conditions for the system's fish pond (Schuenhoff et al., 2003). Others have also demonstrated that seaweed can be highly efficient at removing nutrients from effluent waste-water with substantial nutrient ( $N$ and $\mathrm{P}$ ) reductions of 30-82\% (Neori et al., 1998, Copertino et al., 2009). Not all seaweed species are equally suited to be incorporated in both pond and tank systems. For example, Paul and De Nys (2008) show culturing of Caulerpa species is not straightforward, but might work well in tank-based systems or can be used to treat effluent of ponds.

Besides the effectiveness of seaweed in filtering out nutrients, and forming an additional source of food and/or feed, there are important aspects related to the risk assessment to take into account. These are mainly related to uptake, sorption, and degradation rates of e.g., VMPs, heavy metals, and other chemicals. Owing to their hydrophobicity seaweeds can easily associate with pesticides (GarcíaRodríguez et al., 2012, Lorenzo et al., 2012), which has applications in phycoremediation: for example Liminaria digitata was shown to be effective at reducing levels of diflubenzuron, lindane, copper, and cadmium (Anacleto et al., 2017). Yet, it obviously also poses a risk to human health through potential bioaccumulation and subsequent exposure to contaminated food. Pesticides have even been found in wild seaweed (Pavoni et al., 2003, Moreno et al., 2007, García-Rodríguez et al., 2012, Lorenzo et al., 2012), this seems more likely to happen with seaweed in closed (semi-circulated) pond/tank systems that may, in turn, be part of a larger system of interconnected ponds. Yet, monitoring data is scarce and thus currently the risk to human health is difficult to assess (Banach et al., 2020).

\subsection{Integration with ERA-AQUA}

Integrated multi-trophic systems can have varying levels of complexity (Figure 3), but given that they are modular by design (e.g., Shpigel and Neori 1996, Schuenhoff et al., 2003), the transfer of mass between compartments should in principle be quantifiable. 


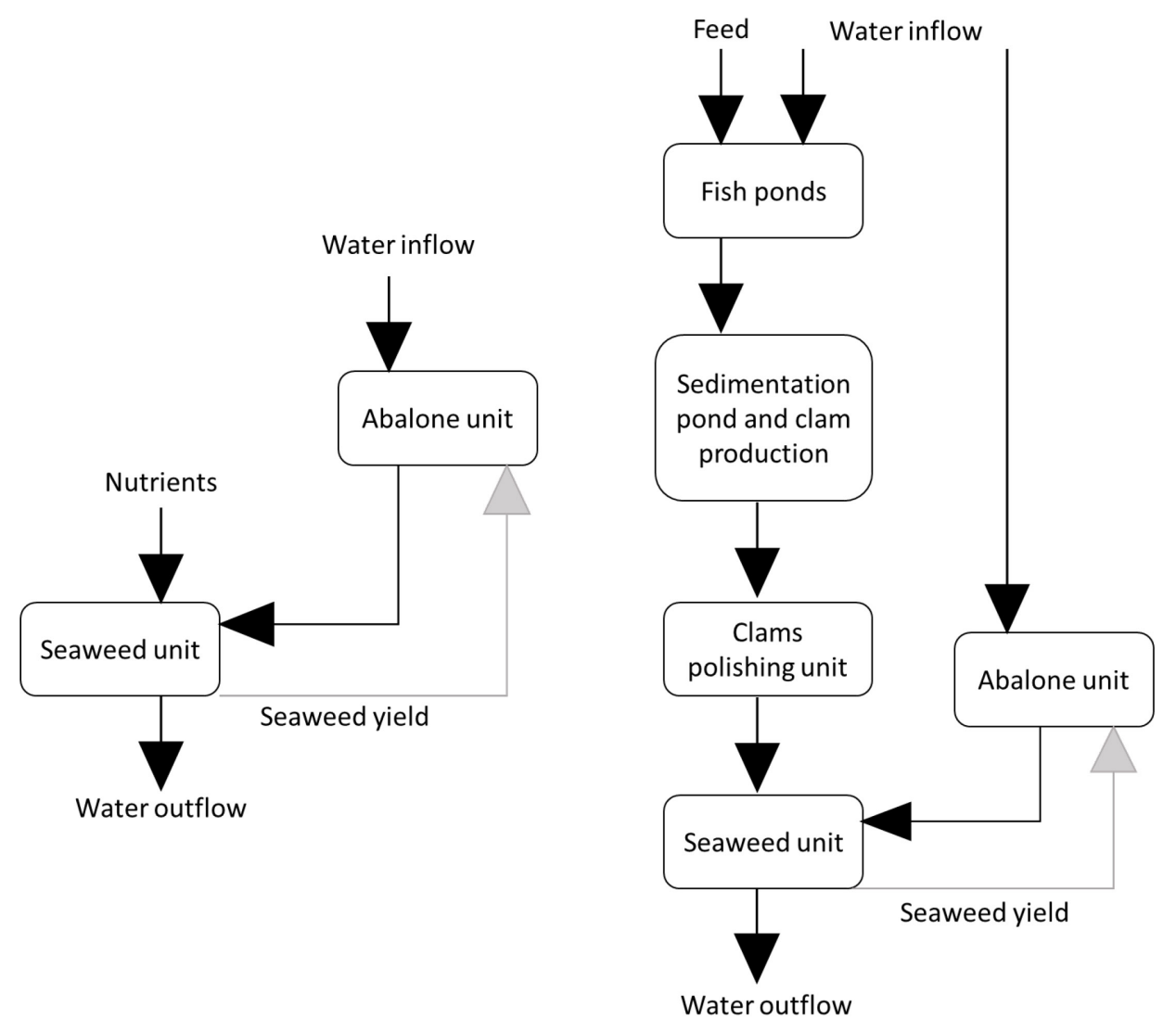

Figure 3 Two examples of integrated multi-trophic systems of differing complexity. On the left is a two-species system, on the right a four-species unit with processing units. Reproduced from: Shpigel and Neori (1996).

The ERA-AQUA has a similar modular set-up (Figure 4), which means an in-line seaweed unit can be integrated in the model. In the current version of the model the risk of exceeding a threshold value by a risk quotient (RQ) is already incorporated for micro-algae. This RQ is based on the ratio between maximum Predicted Environmental Concentration (PEC) and the so-called Predicted No Effect Concentration (PNEC). Here the PEC is based on the total water concentration from dissolved and sorbed fractions and the PNEC is based on a 50\% effect concentration divided by safety factors of 100 and 10 for acute and chronic risk, respectively (Rico et al., 2013). The RQ is used a measure for how far removed the concentrations are from any negative effects on a target species. This is usually done for both for acute and chronic toxicity, where different assessment factors are applied. If an RQ is below 1, the risk is deemed low; between $1-10$ there is an exceedance of acceptable risk; for RQs > 10 there is a large exceedance of acceptable risk. However, the current model does not have a compartment that explicitly models the changes in mass fluxes when multiple compartments and/or seaweeds are taken into account. 


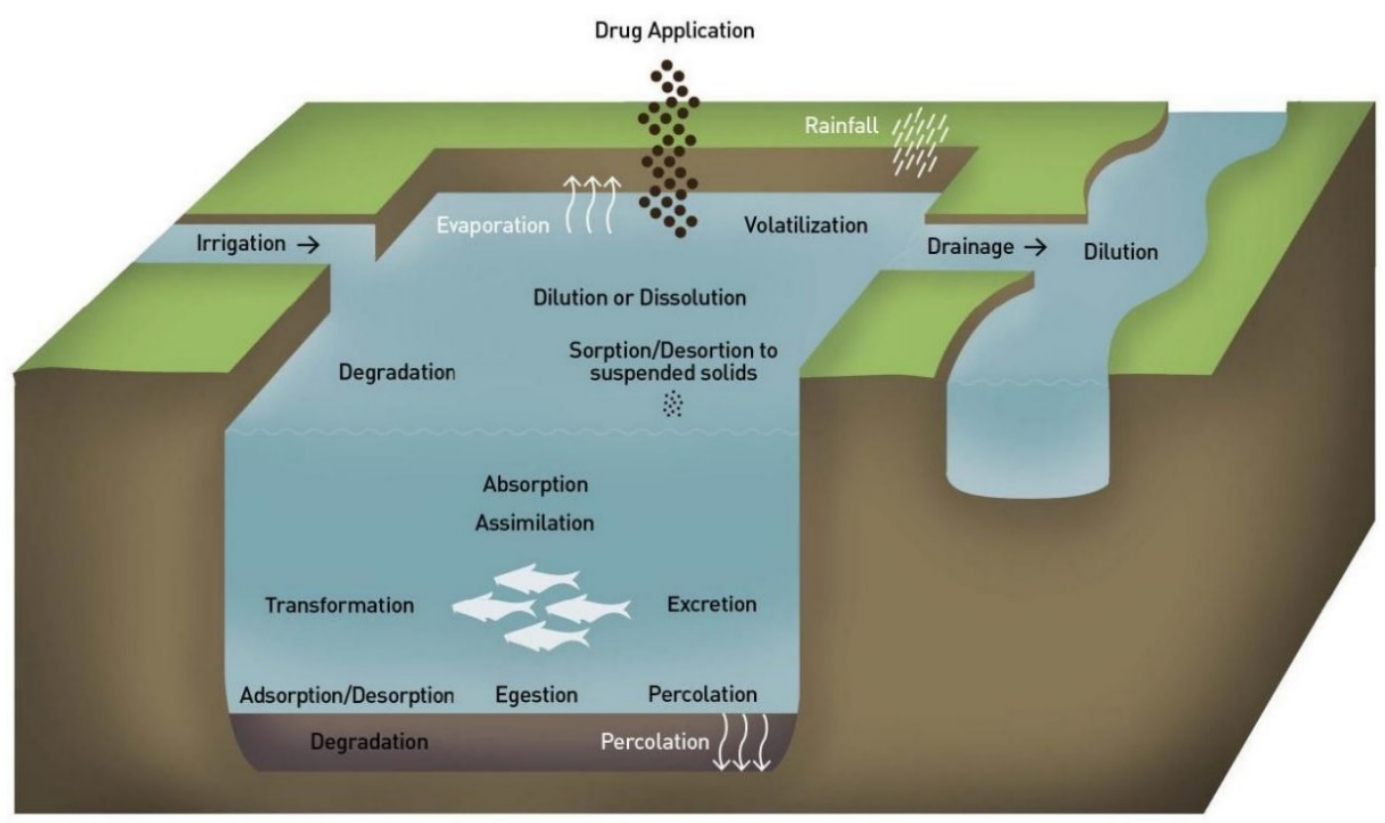

Figure 4 Processes describing drug transfer and dissipation included in the ERA-AQUA model. Source: Rico et al., (2013).

Looking at Figure 3, the ERA-AQUA model can in theory be applied to each of the compartments within an integrated system. For each pond and species, one would set up the pond characteristics, cultured species characteristics, planned stocking and harvest times, and feed administration regimes (which includes a feed conversion rate that could be altered by including seaweed as feed). For the water exchange management the water inflow and water outflow from the separate compartments can form inputs for irrigation and drainage in ERA-AQUA. Thus each compartment can be modelled as 'standalone' unit that receives inputs/outputs at each timestep. Depending on the characteristics of the compartment, e.g., some compartments might be earthen ponds, others can be tanks, the parameters describing the processes related to substance mass balance can be adjusted accordingly.

In the simplest form a multi-compartment system is linear, i.e., there is no recirculation of water and transfer of biomass between them. In such a scenario the only role seaweed would have is as bioremediation of effluent water, and the risk would simply be the risk of the cultured species and the risk of contaminated effluent water re-entering the environment.

In more complex systems, part of the seaweed yield may be used as feed and/or food. This requires a growth model for seaweed, potential reductions in growth/photosynthesis following exposure.

Additionally, the frequency and amount of harvest needs to be known as well as the additional inputs of chemicals (e.g., VMPs and anti-fouling agents) adsorbed to or bioaccumulated in seaweed that is moved into the receiving compartments. Additionally, if the system has some form of recirculation, the additional inputs of VMPs from the recirculated water need to be taken into account for the receiving compartment. These extensions are not currently available in the ERA-AQUA, but could have potential in the environmental risk assessment of integrated multi-trophic aquaculture.

A major caveat is a general lack of information in the literature with respect to seaweed and chemical risk assessment, with implications for food safety (Banach et al., 2020). Indeed, there is evidence that seaweed can take up pesticides and other compounds very efficiently (Lorenzo et al., 2012, Cheney et al., 2014, Anacleto et al., 2017), but there is a lack of uptake, bioaccumulation, and effects studies under laboratory conditions for seaweed species.

A quick search in Web of Science yielded only five results when using the search:

- $A L L=$ (seaweed bioaccumulation chemical effect)

Of these five, only one dealt with herbicides (Ojemaye et al., 2020) and the remaining four look at metal concentrations (Villares et al., 2005, El-Said 2013, Rangabhashiyam et al., 2016), or C-14 
bioaccumulation (Begg et al., 1992). Others have detected pesticides in seaweed from samples taken from the field (e.g., Pavoni et al., 2003, Polat et al., 2018, Sundhar et al., 2020, Contarini and Dromard 2021), whereas only few have studied uptake and bioaccumulation in a laboratory setting (Sikka et al., 1976). Such studies, with commonly used pesticides and/or VMPs would be useful for parameterisation of a seaweed compartment. Notwithstanding the scarcity of studies looking at uptake, bioaccumulation, and effects of chemicals for seaweed species, it appears conceptually possible to include a seaweed compartment into the ERA-AQUA model. With such an addition, it can be used in the risk assessment of integrated multi-trophic aquaculture systems. Given the expected increase in the number of these systems, it would seem a good opportunity for development and further research. 


\section{$4 \quad$ Summary and conclusions}

This document provides a first approach to evaluate the needs and possibilities for an environmental risk assessment for chemicals used in seaweed (co-)productions systems. The investigations concerning open sea production systems indicate that for the control of pests and diseases in the described cultivation systems only prevention, monitoring and mechanical/physical measures are common in Indonesia. However, practices may be different in other major seaweed producing countries like China and Chili. Notwithstanding the apparent low risk for the environment resulting from the use of chemicals, other environmental risks are associated with large scale commercial seaweed farming. Campbell et al., (2019) identified three key drivers for environmental change: facilitation of disease, alteration of population genetics, and wider alterations to the local physiochemical environment. Risk analyses for these aspects are possible, but not within the field of ERA for chemicals.

In contrast to the findings from open sea cultivation methods, results from closed, pond- or tankbased multi-trophic systems where seaweed can be included for example as feed or filter, or for biomass production, indicate some reasons for concern. Uptake and sorption of veterinary medicinal products (VMPs) and other chemicals can lead to additional input to shrimp and/or fish (via feed) or to the environment (via disposal of filter material). Owing to their hydrophobicity pesticides can easily associate with seaweeds. This obviously also poses a risk to human health through potential bioaccumulation and subsequent exposure to contaminated food. The ERA-AQUA model, originally developed for risk assessment of aquaculture production of fish and shrimp, was identified as possible means to further explore the fate of chemicals used in land-based multi-trophic production systems, for their bioaccumulation and biomagnification potential and possible risk for the environment, the produced goods (fish/shrimp), and finally human health. 


\section{References}

Anacleto, P., F. H. M. van den Heuvel, C. Oliveira, R. R. Rasmussen, J. O. Fernandes, J. J. Sloth, V. Barbosa, R. N. Alves, A. Marques, and S. C. Cunha. 2017. Exploration of the phycoremediation potential of Laminaria digitata towards diflubenzuron, lindane, copper and cadmium in a multitrophic pilot-scale experiment. Food and Chemical Toxicology 104:95-108.

Banach, J. L., E. F. Hoek-van den Hil, and H. J. van der Fels-Klerx. 2020. Food safety hazards in the European seaweed chain. Comprehensive Reviews in Food Science and Food Safety 19:332-364.

Begg, F. H., G. T. Cook, M. S. Baxter, E. M. Scott, and M. McCartney. 1992. Anthropogenic radiocarbon in the eastern irish sea and scottish coastal waters. Radiocarbon 34:707-716.

Bjørndal, T., and A. Tusvik. 2019. Economic analysis of land based farming of salmon. Aquaculture Economics \& Management 23:449-475.

Campbell, I., Kambey, C.S.B., Mateo, J.P. et al., 2020. Biosecurity policy and legislation for the global seaweed aquaculture industry. J Appl Phycol 32, 2133-2146. https://doi.org/10.1007/s10811019-02010-5

Campbell I., Macleod A., Sahlmann C., Neves L., Funderud J., Overland M., Hughes A.D., Stanley M. 2019. The environmental risks associated with the development of seaweed farming in Europeprioritizing key knowledge gaps. Front Mar Sci 6:1-22

Cheney, D., L. Rajic, E. Sly, D. Meric, and T. Sheahan. 2014. Uptake of PCBs contained in marine sediments by the green macroalga Ulva rigida. Marine Pollution Bulletin 88:207-214.

Contarini, P.-E., and C. R. Dromard. 2021. Biosorption capacity of genus Dictyota facing organochlorine pesticide pollutions in coastal areas of the Lesser Antilles. Aquatic Botany 169:103346.

Chopin, T., C. Yarish, R. Wilkes, E. Belyea, S. Lu, and A. Mathieson. 1999. Developing Porphyra/salmon integrated aquaculture for bioremediation and diversification of the aquaculture industry. Journal of Applied Phycology 11:463.

Copertino, M. d. S., T. Tormena, and U. Seeliger. 2009. Biofiltering efficiency, uptake and assimilation rates of Ulva clathrata (Roth) J. Agardh (Clorophyceae) cultivated in shrimp aquaculture waste water. Journal of Applied Phycology 21:31-45.

Cruz-Suárez, L. E., A. León, A. Peña-Rodríguez, G. Rodríguez-Peña, B. Moll, and D. Ricque-Marie. 2010. Shrimp/U/va co-culture: A sustainable alternative to diminish the need for artificial feed and improve shrimp quality. Aquaculture 301:64-68.

Debrot, A. O. (Author). (2020). Zeewier als duurzame voedselbron. Web publication/site, Wageningen University \& Research. https://weblog.wur.nl/uitgelicht/zeewier-als-duurzame-voedselbron/ (Accessed 11-05-2021).

Eggertsen, M. \& Halling, C. 2020. Knowledge gaps and management recommendations for future paths of sustainable seaweed farming in the Western Indian Ocean. Ambio https://doi.org/10.1007/s13280-020-01319-7

El-Said, G. F. 2013. Bioaccumulation of Key Metals and Other Contaminants by Seaweeds from the Egyptian Mediterranean Sea Coast in Relation to Human Health Risk. Human and Ecological Risk Assessment 19:1285-1305.

Evans, F., and C. J. Langdon. 2000. Co-culture of dulse Palmaria mollis and red abalone Haliotis rufescens under limited flow conditions. Aquaculture 185:137-158.

FAO. 2018. The state of world fisheries and aquaculture 2018 - meeting the sustainable development goals. Food and Agriculture Organisation of United Nations, Rome

FAO. 2020a. The State of World Fisheries and Aquaculture 2020. Sustainability in action., Rome.

FAO. 2020b. Towards sustainability in the shrimp industry.

FAO Globefish. 2020. GLOBEFISH Trade Statistics - Salmon.

García-Rodríguez, D., R. Cela-Torrijos, R. A. Lorenzo-Ferreira, and A. M. Carro-Díaz. 2012. Analysis of pesticide residues in seaweeds using matrix solid-phase dispersion and gas chromatography-mass spectrometry detection. Food Chemistry 135:259-267.

Hurtado A.Q., Critchley A.T., Neish I.C. (eds) 2017. Tropical seaweed farming trends, problems and opportunities: focus on Kappaphycus and Eucheuma of commerce. Springer, Cham 
Hurtado, A. Q., \& Critchley, A. T. 2006. Occurrence of Polysiphonia epiphytes in Kappaphycus farms at Calaguas Is., Camarines. Norte, Philippines. Journal of Applied Phycology, 18, 301-306.

Hurtado A.Q., Gerung G.S., Yasir S., Critchley A.T. 2014. Cultivation of tropical red seaweeds in the BIMP-EAGA region. J Appl Phycol 26:702-718

Ingle K.N., Polikovsky M., Chemodanov A., Golberg A. 2018. Marine integrated pest management (MIPM) approach for sustainable seagriculture. Algal research 29, 223-232

Kim, G. H., Moon, K.-H., Kim, J.-Y., Shim, J., \& Klochkova, T. A. 2014) A revaluation of algal diseases in Korean Pyropia (Porphyra) sea farms and their economic impact. Algae, 29, 249-265.

Largo, D. B., Fukami, K., \& Nishijima, T. (1995). Occasional pathogenic bacteria promoting ice-ice disease in the carrageenanproducing red algae Kappaphycus alvarezii and Eucheuma denticulatum (Solieriaceae, Gigartinales, Rhodophyta). Journal of Applied Phycology, 7, 545-554.

Liu, Y., T. W. Rosten, K. Henriksen, E. S. Hognes, S. Summerfelt, and B. Vinci. 2016. Comparative economic performance and carbon footprint of two farming models for producing Atlantic salmon (Salmo salar): Land-based closed containment system in freshwater and open net pen in seawater. Aquacultural Engineering 71:1-12.

Lorenzo, R. A., S. Pais, I. Racamonde, D. García-Rodríguez, and A. M. Carro. 2012. Pesticides in seaweed: optimization of pressurized liquid extraction and in-cell clean-up and analysis by liquid chromatography-mass spectrometry. Analytical and Bioanalytical Chemistry 404:173-181.

McHugh, D.J. A. 2003. Guide to the Seaweed Industry; FAO Fisher: Rome, Italy, 2003.

Moreno, D. V., Z. S. Ferrera, and J. J. S. Rodríguez. 2007. SPME and SPE comparative study for coupling with microwave-assisted micellar extraction in the analysis of organochlorine pesticides residues in seaweed samples. Microchemical Journal 87:139-146.

Neori, A. 2009. Essential role of seaweed cultivation in integrated multi-trophic aquaculture farms for global expansion of mariculture: an analysis. Pages 117-120 in M. A. Borowitzka, A. T. Critchley, S. Kraan, A. Peters, K. Sjøtun, and M. Notoya, editors. Nineteenth International Seaweed Symposium: Proceedings of the 19th International Seaweed Symposium, held in Kobe, Japan, 26-31 March, 2007. Springer Netherlands, Dordrecht.

Neori, A., N. L.C. Ragg, and M. Shpigel. 1998. The integrated culture of seaweed, abalone, fish and clams in modular intensive land-based systems: II. Performance and nitrogen partitioning within an abalone (Haliotis tuberculata) and macroalgae culture system. Aquacultural Engineering 17:215-239.

Neish I.C. 2013. Some social and economic dimensions of seaweed aquaculture in Indonesia. In: Valderrama D, Cai J, Hishamunda N, Ridler N (eds) Social and economic dimensions of carrageenan seaweed farming. Fisheries and Aquaculture Technical Paper No. 580. Rome, FAO

Neish, I. C. 2004. Eucheuma seaplant agronomy, biology and commerce. Marine Botanicals. Sabah, Malaysia.

Ojemaye, C. Y., C. T. Onwordi, D. M. Pampanin, M. O. Sydnes, and L. Petrik. 2020. Presence and risk assessment of herbicides in the marine environment of Camps Bay (Cape Town, South Africa). Science of The Total Environment $\mathbf{7 3 8}$.

Paul, N. A., and R. de Nys. 2008. Promise and pitfalls of locally abundant seaweeds as biofilters for integrated aquaculture. Aquaculture 281:49-55.

Pavoni, B., M. Caliceti, L. Sperni, and A. Sfriso. 2003. Organic micropollutants (PAHs, PCBs, pesticides) in seaweeds of the lagoon of Venice. Oceanologica Acta 26:585-596.

Pereira, R., Yarish, C. 2008. Mass production of marine macroalgae. In S.E. Jørgensen, B.D. Fath (Eds.), Encyclopedia of Ecology, Elsevier (2008), pp. 2236-2247. ISBN 9780080454054, https://doi.org/10.1016/B978-008045405-4.00066-5.

Petrell, R. J., and S. Y. Alie. 1996. Integrated cultivation of salmonids and seaweeds in open systems. Pages 67-73. Springer Netherlands, Dordrecht.

Polat, A., S. Polat, A. Simsek, T. T. Kurt, and G. Ozyurt. 2018. Pesticide residues in muscles of some marine fish species and seaweeds of Iskenderun Bay (Northeastern Mediterranean), Turkey. Environmental Science and Pollution Research 25:3756-3764.

Quiaoit HAR, Uy WH, Bacaltos DGG, Chio PBR (2018) Seaweed area GIS-based mapping. Production support system for sustainable seaweeds farming in the Philippines 2016 report. Xavier University Press, Manila, pp 1-139

Rangabhashiyam, S., E. Suganya, A. V. Lity, and N. Selvaraju. 2016. Equilibrium and kinetics studies of hexavalent chromium biosorption on a novel green macroalgae Enteromorpha sp. Research on Chemical Intermediates 42:1275-1294. 
Rico, A., Y. Geng, A. Focks, and P. J. Van den Brink. 2013. Modeling environmental and human health risks of veterinary medicinal products applied in pond aquaculture. Environmental Toxicology and Chemistry 32:1196-1207.

Rosales, J., J. T. Ponce-Palafox, R.-G. Alma Delia, E. Otazo-Sánchez, G. Pulido-Flores, S. Vargasmachuca, and A. Lara. 2019. Effects of white shrimp (Litopenaeus vannamei) and tilapia nilotica (Oreochromis niloticus var. Spring) in monoculture and co-culture systems on water quality variables and production in brackish low-salinity water earthen ponds during rainy and dry seasons. Spanish Journal of Agricultural Research 17:e0605.

Schuenhoff, A., M. Shpigel, I. Lupatsch, A. Ashkenazi, F. E. Msuya, and A. Neori. 2003. A semirecirculating, integrated system for the culture of fish and seaweed. Aquaculture 221:167-181.

Shpigel, M., and A. Neori. 1996. The integrated culture of seaweed, abalone, fish and clams in modular intensive land-based systems: I. Proportions of size and projected revenues. Aquacultural Engineering 15:313-326.

Sikka, H. C., G. L. Butler, and C. P. Rice. 1976. Effects, Uptake, and Metabolism of Methoxychlor, Mirex, and 2, 4-D in Seaweeds. US Environmental Protection Agency, Office of Research and Development.

Sundhar, S., R. J. Shakila, G. Jeyasekaran, S. Aanand, R. Shalini, U. Arisekar, T. Surya, N. A. H. Malini, and S. Boda. 2020. Risk assessment of organochlorine pesticides in seaweeds along the Gulf of Mannar, Southeast India. Marine Pollution Bulletin 161:111709.

Troell, M., C. Halling, A. Nilsson, A. H. Buschmann, N. Kautsky, and L. Kautsky. 1997. Integrated marine cultivation of Gracilaria chilensis (Gracilariales, Rhodophyta) and salmon cages for reduced environmental impact and increased economic output. Aquaculture 156:45-61.

Uyenco, F. R., Saniel, L. S., \& Jacinto, G. S. 1981. The "ice-ice" problem in seaweed farming. Paper presented at the 10th International Seaweed Symposium. New York, NY: Walter de Gruyter, 625-630.

Vairappan, C. S. 2006. Seasonal occurrences of epiphytic algae on the commercially cultivated red alga Kappaphycus alvarezii (Solieraceae, Gigartinales, Rhodophyta). Journal of Applied Phycology, 18, 611-617.

Vairappan, C. S., Chung, C. S., Hurtado, A. Q., Msuya, F. E., Bleicher Lhonneur, G., \& Critchley, A. 2008) Distribution and symptoms of epiphyte infection in major carrageenophyte-producing farms. Journal of Applied Phycology, 20, 477-483.

Valderrama, D., J. Cai, N. Hishamunda, N.B. Ridler, and Food and Agriculture Organization of the United Nations (Eds.). 2013. Social and economic dimensions of carrageenan seaweed farming. FAO fisheries and aquaculture technical paper, 200 pp. Rome: Food \& Agriculture Organization of the United Nations.

Viera, M. P., J. L. Gómez Pinchetti, G. Courtois de Vicose, A. Bilbao, S. Suárez, R. J. Haroun, and M. S. Izquierdo. 2005. Suitability of three red macroalgae as a feed for the abalone Haliotis tuberculata coccinea Reeve. Aquaculture 248:75-82.

Villares, R., E. Carral, X. Puente, and A. Carballeira. 2005. Metal levels in estuarine macrophytes: Differences among species. Estuaries 28:948-956.

Matoju I., Msuya F.E., Bass D., Brodie J. 2019. A review of reported seaweed diseases and pests in aquaculture in Asia. J. World Aquacult. Soc. (2019), 10.1111/jwas.12649.

Ward, G. M., J. P. Faisan, E. J. Cottier-Cook, C. Gachon, A. Q. Hurtado, P. E. Lim, I. Matoju, F. E. Msuya, D. Bass, and J. Brodie. 2020. A review of reported seaweed diseases and pests in aquaculture in Asia. Journal of the World Aquaculture Society 51:815-828.

Waters, T. J. Lionata, H., Prasetyo Wibowo, T., Jones, R., Theuerkauf, S., Usman, S., Amin, I., and Ilman, M. 2019. Coastal conservation and sustainable livelihoods through seaweed aquaculture in Indonesia: A guide for buyers, conservation practitioners, and farmers, Version 1. The Nature Conservancy. Arlington VA, USA and Jakarta, Indonesia.

Watkiss P, Pye S, Hendriksen G, Maclean A, Bonjean M, Jiddawi N, Shaghude Y, Sheikh MA, Khamis Z (2012) The economics of climate change in Zanzibar. In: Vulnerability, Impacts and Adaptation, Technical Report no. 4. Revolutionary Government of Zanzibar (RGZ). Final Summary Report. July 2012. pp 1-36. Available at: http://www.economics-of-cc-inzanzibar.org/images/Final_Summary_vs_3.pdf. Accessed on 26 Nov 2019. 
Wageningen Environmental Research P.O. Box 47

6700 AA Wageningen

The Netherlands

$\mathrm{T}+31(0) 317480700$

www.wur.nl/environmental-research

Wageningen Environmental Research

Report 3113

ISSN 1566-7197
The mission of Wageningen University \& Research is "To explore the potential of nature to improve the quality of life". Under the banner Wageningen University \& Research, Wageningen University and the specialised research institutes of the Wageningen Research Foundation have joined forces in contributing to finding solutions to important questions in the domain of healthy food and living environment. With its roughly 30 branches, 6,800 employees (6,000 fte) and 12,900 students, Wageningen University \& Research is one of the leading organisations in its domain. The unique Wageningen approach lies in its integrated approach to issues and the collaboration between different disciplines. 


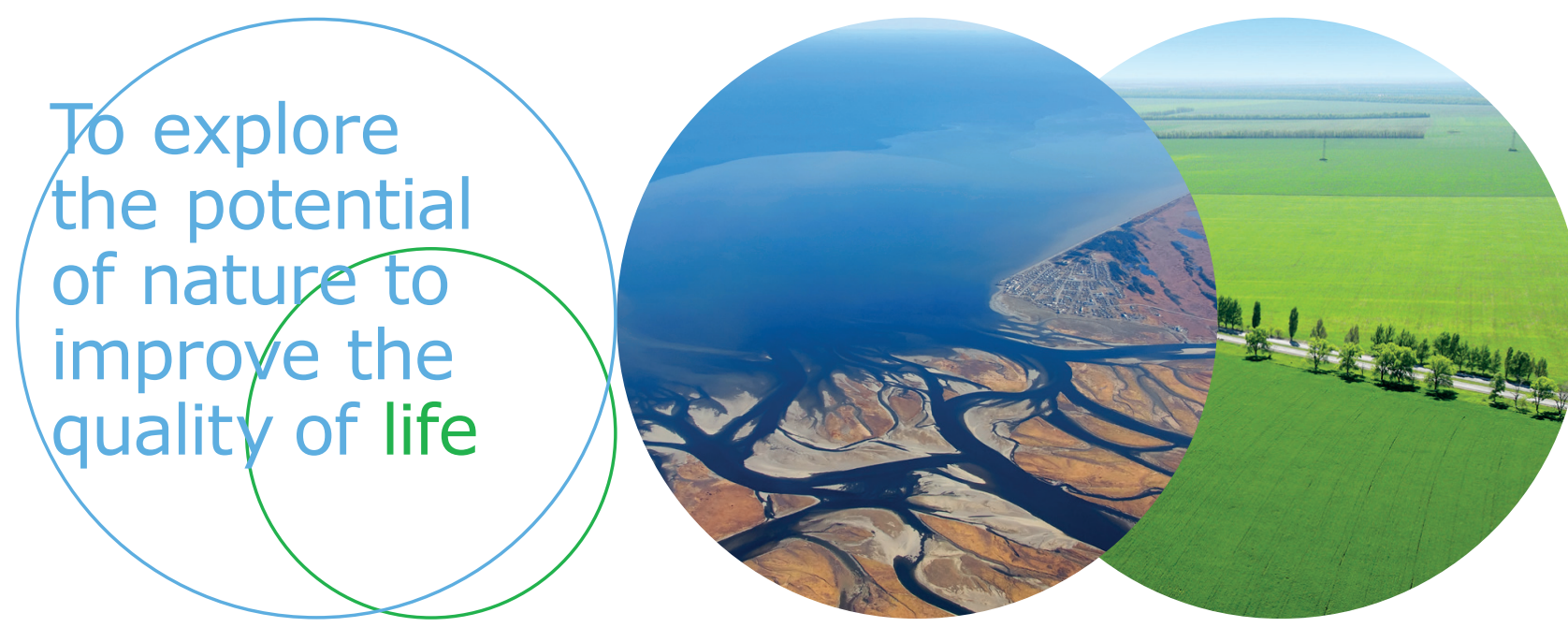

Wageningen Environmental Research Postbus 47

$6700 \mathrm{AB}$ Wageningen

T 317480700

www.wur.nl/environmental-research

Rapport 3113

ISSN 1566-7197
De missie van Wageningen University \& Research is 'To explore the potential of nature to improve the quality of life'. Binnen Wageningen University \& Research bundelen Wageningen University en gespecialiseerde onderzoeksinstituten van Stichting Wageningen Research hun krachten om bij te dragen aan de oplossing van belangrijke vragen in het domein van gezonde voeding en leefomgeving. Met ongeveer 30 vestigingen, 6.800 medewerkers (6.000 fte) en 12.900 studenten behoort Wageningen University \& Research wereldwijd tot de aansprekende kennisinstellingen binnen haar domein. De integrale benadering van de vraagstukken en de samenwerking tussen verschillende disciplines vormen het hart van de unieke Wageningen aanpak. 